\title{
Feminist Finance: Recessionistas, Debt and the Credit Crunch
}

\section{Finanzas feministas: Recesionistas, deuda y la crisis crediticia}

ABSTRACT: This article offers an opposing argument to the «man-cession» narrative that has dominated the press in recent years and explores what makes this particular economic context crucial for contemporary women's fiction, offering a view into the recession's impact on women's lives, reading, consumption patterns, and self-identity in today's post-credit-crunch world. The credit crunch has reignited debates about gender and the workplace in twenty-first century society. This article proposes that tensions between gender and debt have been played out in popular culture post-2007, most notably in publishing, through the emergence of a new genre of literature - Recessionista fiction. In Recessionista fictions, cocktails and heels are eschewed in favour of financial practicality, as shopaholic heroines confront a harsh new reality, forced into a position where they must take stock of their lives and start again from the midst of financial ruin, divorce or a major career change. As part of this process, Recessionista fiction foregrounds the impact of the credit crunch on female identity. This article examines a range of Recessionista fictions to explore how, why and with what effects the heroines of these novels intern and reify the attitudes of society during and after the global credit crunch. Examining an evolution in contemporary fiction that brought a taste of reality to an outdated chick lit genre in danger of extinction, the article analyses representations of gender and debt and the possibilities for personal transformation brought about by the global economic downturn.

Keywords: credit crunch, chick lit, women's fiction, debt, contemporary literature.

RESUMEN: Este artículo ofrece una visión alternativa a las narrativas de «mancession» (desempleo masculino) que han dominado los medios de comunicación en años recientes y explora las condiciones que hacen de este contexto econó- 
mico un elemento crucial para la novela femenina contemporánea, presentando una imagen del impacto de la recesión en la vida de las mujeres, sus lecturas, pautas de consumo e identidad personal en el actual mundo post-crisis crediticia. La contracción del crédito ha reavivado los debates de género sobre el lugar de trabajo en la sociedad del siglo XXI. Este artículo explora las tensiones entre deuda y género en la cultura popular post-2007, especialmente en el sector editorial, a través de la aparición de un nuevo género literario -la novela recesionista-. En las narrativas recesionistas se desechan los cócteles y los tacones en favor del pragmatismo financiero cuando las heroínas adictas a las compras se enfrentan a una nueva y agria realidad, y se ven forzadas a ocupar una posición en la que deben hacerse cargo de sus propias vidas para comenzar de nuevo en medio de la ruina financiera, el divorcio o cambios profesionales significativos. Como parte del proceso, la narrativa recesionista incide en el impacto de la crisis crediticia sobre la identidad femenina. Este artículo examina en un conjunto de novelas recesionistas cómo y por qué las heroínas de estas ficciones rechazan y glorifican las actitudes sociales durante y después de la crisis crediticia global. Al analizar la evolución de la narrativa contemporánea que ha proporcionado un toque de realidad al género pasado de moda de una literatura romántica en peligro de extinción, el artículo aborda las representaciones de género y deuda en relación con las posibilidades de transformación personal derivadas del deterioro económico global.

Palabras clave: crisis crediticia, literatura romántica, literatura femenina, deuda, literatura contemporánea.

Occupying a majority of roles in some of the sectors hardest hit by the global economic downturn - including retail, services, local government and the public sector - the independence and equality of women in the workplace became one of the first threats of the twenty-first century credit crunch. In the UK in the year leading up to October 2008, 53,000 women lost their jobs, while the gender pay gap increased from $17 \%$ in 2007 to $17.1 \%$ on the basis of mean full-time hourly earnings. As journalist Ruth Sutherland argues in her analysis of the unseen impact of the crunch on women, «to the many thousands of female workers who have lost their jobs, the recession may well look like a case of highlypaid men creating a mess, and low-paid women suffering the consequence»» (Sutherland, 2009). The popular press also sought to understand the causes and consequences of the credit crunch through a specifically gendered response, measuring the impact of the recession on women's shopping, socialising and spending habits. The so-called «lipstick effect» became associated with periods of economic downturn post-9/11. The term refers to the continued sales of 
expensive make-up products during times of recession and is concerned with examining how and why economic recessions influence women's consumer behaviour.

In her feminist blog The F Word, Carolyn Roberts conducted her own small scale survey of press headlines connecting the credit crunch and its effect on female consumption and identity. She found a depressing range including: «a story about an overweight woman who lost her job, started her own business and lost five stones»; «the reassuring news that the credit crunch is not affecting cosmetic sales» (apparently because women would rather go without food than makeup - or more accurately, women shopping on a beauty product website); a cosmetic surgery company's announcement of a $135 \%$ increase in breast augmentation procedures, with the tasteful statement, «as the economy is going bust, UK women are boosting theirs». These appearance orientated stories were completed by a range of articles on ways to beat the credit crunch, strategies for continuing to dress stylishly and have expensive haircuts whilst apparently on a budget. Roberts concluded that «even in recession, a woman's appearance is perceived as her most interesting facet. Articles aimed at women assume that our interest in finance begins and ends with whether we can still afford to buy lipstick» (Roberts, 2008).

Articles in women's magazines quickly appeared asking their readers how the credit crunch had affected their beauty regime and crunch-inspired fitness plans (including the use of workout DVDs and gym balls to avoid «those costly gym memberships»). Articles examined how readers were learning to make home-made cocktails or reasons for the apparent rise in the popularity of dinner parties and home cinema nights as an alternative way of surviving and socialising through the crunch. Occupied with credit crunch diets - based on own brands and lower fat alternatives - cut price holidays and credit crunch Christmas plans, the message of the popular press was clear: women should look on the bright side of the global economic downturn, more time with their partner (now unemployed), losing weight (thanks to a distinct drop in the number of restaurants visited), greater food economy (with no spare cash for luxuries or waste) and a new found appreciation for the little things in life.

The publishing industry was not immune from the crunch. Post-2007, some chick lit authors claimed that the recession had caused the death of their genre as a direct result of the change in social circumstances it had brought about. Author of best-sellers Bergdorf Blondes and The Debutante Divorcee, Plum Sykes, argued that she could «not set another book in modern-day America because of the credit crunch» because the crunch «just doesn't work» as a context for social comedies. For Sykes, the crunch brought with it the last «sex 
and shopping book as a publishing phenomenon» because it made chick lit seem «out of date [...] not only because of the economic reality but because it's been done to death» (Sykes in Mesure, 2009). However, from this new economic reality, «Recessionista fiction» developed from a set of emergent tropes, plots and, as a new publishing category, surfaced from the credit crunch and the legacy of chick lit that had dominated the previous decade of fiction. These novels come from both US and British authors and examine the impact of a global recession on the lives of women in the countries' most iconic capitals of consumption, New York and London.

Recessionista fiction compares to the novels of economic downfall published in very different eras (such as Trollope and Wharton) in that it seeks to understand the wider impact of market shifts through a close focus on the lives of specific individuals who fall victim to its immediate after effects. What makes this particular economic context crucial for contemporary women's fiction is both the role of literature as a means of shaping and making sense of seemingly impossible real-life events but also making visible the effects of the crisis of a generation of women for whom many of the advances of the past thirty years were now under threat. In the wake of a twenty-first century credit crunch, women's fiction became the appropriate venue for these socioeconomic fears to be aired, explored and rationalised.

Exploring excessive spending and conspicuous consumption, Recessionista fictions can be seen a logical development of the «sex and shopping novels» of the 1980s that emerged under Thatcher and Reagan. These novels represented heroines concerned with wealth and excess, luxury, glamour and self-presentation through purchase power. Promoting the dominant ideals of the period - individualism and independent enterprise $-\langle\mathrm{S} \& \mathrm{~F} »$ heroines were marked by self-interest and a rejection of any perceived value in terms of sisterhood or feminism as personal ambition instead reigned supreme and objects and labels dominated friends and feminist politics. The 1990s witnessed a further development from this trend in the growth of chick lit as a recognised genre of fiction, led by the emergence of Bridget Jones as literary and social phenomenon. The heroine of the chick lit novel, like those of the «S\&F» fictions, had a career and was financially independent but did not define herself through her work, instead using employment to fund her lifestyle choices. As Deborah Philips argues, chick lit heroines take «great pleasure in conspicuous consumption [...] and the opportunities afforded by the multiplication of consumer goods for women who are in a position to afford them» (Philips, 2006: 116).

Yet these women are also deeply unsatisfied, and often search for a man or love interest as a perceived plug to fill this void. As Mallory Young argues, 
«chick lit usually responds through comedy to real situations confronting real women» (Young quoted by La Ferla, 2009). Unlike the convivial Romance genre, chick lit «recognizes and responds to the world outside» (La Ferla, 2009). Recessionista fiction continues this outward looking awareness of socioeconomic and political contexts but draws on the global economic crisis in structure and subject matter. Focussing on the social fallout of the credit crunch and using female characters to examine a wider social and economic transition from lives of sex and shopping to monogamy and austerity, these explicitly cautionary tales (with many even using this term as a subtitle) follow yummy mummies forced to cut up their credit cards, with husbands in prison for fraud and financial mismanagement. Recessionista fiction explores a change of situation and lifestyle as well as a perceived fall from grace: social, economic or political.

The term «Recessionista» may imply a lifestyle choice but is actually exposed by these fictions as an insulting term for those who have no choice and are forced into the role by circumstance. Recessionista fiction reflects «the biggest story of the last two years», according to Jonathan Segura, deputy editor at US Publishers Weekly. He argues that «it would be impossible to write contemporary glitzy women's fiction without taking the recession into account» and predicts a future «flood of new fiction dealing specifically with the big meltdown» (Segura in La Ferla, 2009). Keshini Naidoo, commissioning editor at Avon, also argues that Recessionista lit «perfectly fits the mood of the times». Naidoo suggests that traditional chick lit of the 1990s could never hope to survive into the new circumstances of the post-crunch. She reflects that «after the downturn in the economic climate, blockbusters that glorified excessive, conspicuous consumption threatened to look both in poor taste and deeply out of touch with what readers are experiencing». Centering on social and economic struggles, Recessionista fictions are instead aimed at readers who now have zero sympathy for the shopaholic protagonists of previous best-sellers. Rather than signaling the demise of the chick lit genre that dominated bookshop sales for so long, Recessionista fiction has injected it with new lifeblood. Naidoo argues that while some readers consider characters that simply shop and spend to be inappropriate in a post-crunch period «there is still a thirst for glamorous fiction that details an aspirational lifestyle», but also an increasing market for novels «that show the tarnish behind these gilded lifestyles» partly fuelled by «a sense of schadenfreude on the part of readers» (Naidoo in Mesure, 2009).

Recessionista fiction develops a long standing fascination with the excesses and deviant behaviours of the other half of society. In «this spate of new fiction $[\ldots]$ tackling the recession and its attendant woes» darkly funny tales of divorce 
meet even darker explorations of debt and excessive spending as the credit crunch overshadows characters» lives (La Ferla, 2009). However, unlike its «S\&F» and chick lit predecessors, Recessionista fiction has an added feminist dimension to this development through female characters who are forced into a position where they must take stock of their lives and start again after the crunch causes them debt, divorce or a major career change.

In Recessionista fiction, the credit crunch functions as an occasion for female characters to stop these binges and examine their own sense of self. The heroines of Recessionista fiction are used to tackling their doubts through purchase power, employment or relationships. In the wake of the crunch, they are forced to re-consider the sources from which they draw their identity and define both themselves and their purpose in the post-crunch world. Faced with doubt and a perceived void of purpose post-crunch, consumption as a form of agency no longer offers these women an easy means of constructing the self. In Hedge Fund Wives, this is confronted through the power of purchase as Marcy reflects on how she is drawn to shop because «the saleswomen treated you the way you wish your husband still did» (Boncompagni, 2009: 136). As part of the construction of self, consumption operates in Recessionista fiction to define the heroine during a point of change or flux. Set in and written by a UK author, in Confessions of a Reluctant Recessionista protagonist Cassie goes on shopping sprees with her credit card to get over losing her job, the agencies not taking on people and splitting up with Dan. Shopping takes the place of work in her day to day life but also offers a new sense of purpose, focus and identity - an option denied to her by the depressed employment market of the twenty-first century. However, these identity-searching spending sprees also position Cassie in a huge amount of debt.

Recessionista fiction focuses on «debt's harmful behaviour» (Atwood, 2009: 42) and the effects this can have on the psychological and social standing of the female protagonist. Western society is heavy with metaphors of debt and informed by the language of debt or owing. Debt, Margaret Atwood argues, is «like air», we are surrounded by it and therefore «never think about it unless something goes wrong with the supply» (Atwood, 2009: 9). Attitudes towards debt are «deeply embedded in our entire culture» (Atwood, 2009: 10) and are also a product of that culture. Debt also carries with it connotations of shame and social judgement. From the debtors prisons and workhouses of the nineteenth century to the credit card companies and payday loan advances of the present, «Debt is the new fat» (Atwood, 2009: 40) of the twenty-first century, a source of anxiety, stigma and debate but also an increasingly important element of personal identity.

Atwood pays particular attention to the poisonous activities brought on by readily available credit and in particular its effects on women. She recalls 
accounts of shopaholic binges during which you don't even know what came over you and everything was a blur, with tearful confessions by those who've spent themselves into quivering insomniac jellies of hopeless indebtedness, and have resorted to lying, cheating, stealing and moving cheques between bank accounts as a result. (Atwood, 2009: 42).

Following this binge and purge model, there then follows «a penance imposed - snip, snip go the scissors on the credit cards - followed by a strict curb-on-spending regime; and finally, if all goes well, the debts are paid down, the sins are forgiven, absolution is granted, and a new day dawns» (Atwood, 2009: 42). In the shadow of the crunch even the wives of bankers, hedge fund managers and private equity partners were forced to curb their designer habits. One senior female investment banker said: «some of these women were in LaLa land. When their husbands told them to cut back on the Chanel, they didn't listen, they just didn't seem to know what was going on, but they have had to stop spending now» (La Ferla, 2009).

Such conspicuous consumption is often a target of criticism in the popular press, but in Recessionista fiction it is also a catalyst for change. As Susie Mesure suggests, the new heroine of Recessionista fiction has «had to cut up her credit cards, take her kids out of private school, and, gasp, even think about finding a job to try to plug the gaping hole in the family finances» (Mesure, 2009), confronting the rapid period of growing up experienced by many in the wake of the crunch and the drying up of ready credit for consumption and excessive lifestyles. Witnessing the excesses of her spending sprees and the credit card bills that follow, Cassie is forced to consider the reasons behind her consumption binges. The objects she purchases and the bills documenting her actions function to make this problem visible to her friends, who stage an intervention. Instructed that she "can't just spend your way out of every problem you ever have» (Silver, 2009: 99), Cassie realises the need to go on an «anti-extravagance drive» (Silver, 2009: 105) and live within her means. She reasons that, «for as long as I was unemployed, for as long as this blasted recession lasted, I was going to have to stop living like a rich person» (Silver, 2009: 149). This involves experimenting with new sources of identity such as a «clothes swap party» (Silver, 2009: 165) in which the participants can literally try on alternative lifestyles and adopt a general «Less Is More spirit» (Silver, 2009: 166) of austerity and economy more in keeping with the times. Rejecting a previous reliance on «totems of excess», Recessionista fiction follows heroines as they battle with the trauma of a loss of consumption and the identity it brings (La Ferla, 2009). Confronted with reduced circumstances, a crisis of 
self and professional and emotional breakdowns of relationships, the women of Recessionista fiction use life-changing events as catalysts to awareness raising activities. Moving through an arc of anger and denial to depression and acceptance, this new form of recession literature is characterised by motifs of empowerment and realigned values, as female characters rediscover the value not just of things, but of people and behaviour.

The collapse of the banking system is echoed in Recessionista fictions by the breakdown of personal relationships. When Cassie is dumped by trader Dan, she is forced to re-evaluate her situation and lack of aspiration in the workplace. Breaking up with her trader boyfriend leads Cassie to a realisation that the financial world is «shallow and consumerist, they're obsessed with money and cars and clothes and things. Things, things, things. The men are pigs and the women know that unless they fit in with the boys they'll be harassed to within an inch of their loves, so most of them end up being pigs too» (Silver, 2009: 201). An important part of this realisation is Cassie's reignited sense of ambition and passion for her own career. Despite working in the financial industry all her life, her relationship breakdown and newly unemployed state make her realise that she

was never interested in how the markets work, how the traders make their money. I didn't care what a derivative was or whether Bank X merged with Bank Y and what the implications of that would be. My mother was right. Mothers usually are. I had to get myself a job in a field that I was at least vaguely interested in. (Silver, 2009: 205).

Cassie goes on to explore a wide range of career options, including temping (difficult in times of economic downturn), walking dogs for money, and volunteering. She finally hears about an administrative role in an independent wine company through her dog walking contacts, making a shift from a large corporate organisation to an start-up company where she earns her stripes and is rewarded with promotion. At the end of the novel Cassie is «moving on to greater things» (Silver, 2009: 313), away from the city, traders and Louboutins.

Financial recompense is presented as the ultimate consolation in Recessionista fiction, often as a form of payment for services given. Written by an American author and set in Northern America, Hedge Fund Wives uses the paratext of the novel to advertise its tale as situated deep «in the throes of the credit crunch». While the financial downturn and its immediate effects in America dominate the text, the novel is equally framed by the divorce of the protagonist and the emotional as well as financial fallout from the crunch. Marcy, a heroine newly arrived in New York as the wife of a hedge fund manager from Chicago, finds 
herself «surrounded by hedge-fund wives» in a city where there is, initially at least, «nothing but the promise of pleasure» (Boncompagni, 2009:1). However, as an ex-financier herself, Marcy is quick to realise that conditions are changing. While the other wives turn their heads she reflects that

although no one spoke of it, the economy had begun to sour and every day brought fresh tales of falling fortunes. Most of the women assumed that their vast monetary reserves would protect them from having to alter any aspect of their enviable lives, but of course they were wrong. Wealth is relative by nature, and if one day you have a hundred, billion dollars and the next you have only fifty, the things that were once within reach $[\ldots]$ are suddenly out of it. Under such circumstances, it's not long before a marriage built around material possessions and predicated upon the shared responsibility of their care and maintenance, begins to crumble. (Boncompagni, 2009: 2-3)

As our voice on the credit crunch, Marcy reminds the readers that the «long run of American prosperity was coming to an end» (Boncompagni, 2009: 32) and that this would be most sharply felt in «hedgefundlandia» (Boncompagni, 2009: 39).

When the crunch hits, Marcy's husband John develops a cocaine addiction and to painkillers to cope with pressure but refuses to allow Marcy to return to work, perceiving a working wife as a reflection on his own financial shortcomings. Marcy is unable to understand her husband's desire to make «money for the pure sport of it» and wishes he could instead «manufacture a product». As she watches, the wives carry on spending «despite the darkening economic clouds, despite the millions of foreclosure signs popping up across the country like little red flags. A storm was coming, but no one wanted to see it, least of all, of course, the wives» (Boncompagni, 2009: 67). Marcy reflects on «feeling worried about the world in general» (Boncompagni, 2009: 171) on several occasions before the revelation that her husband has cheated on her and impregnated another hedge fund wife while he was supposed to be trying for a baby with her. The behaviour of her husband, and the betrayal by a so-called fellow hedge fund wife, motivate Marcy to take stock of her new life in New York, to re-focus on herself, return to the world of work and begin to work as a writer again. It is only when she is happy at work, successfully divorced and settled with her son that Marcy meets her dream man and remarries. She ends the novel with her own business, pregnant with another child and conveniently married to a billionaire. The message is simple - Recessionistas who heed the call of debt and ride out the crunch are rewarded with personal, professional and emotional success. 
Recessionista fiction also highlights a hitherto unrepresented creature the female trader. In Silver's novel, Cassie literally looks in on the trading floor as a PA and explains to readers that there are a

handful of women on the floor [...] They have to work seventy-hour weeks in what is sometimes an unbearable environment - the stories you hear about misogyny and bullying in the City are fairly accurate. The pretty girls spend their time fending off the unwanted advances and the less pretty girls have to put up with incessant cruel remarks» (Silver, 2009: 24). Cassie's trader friend Ali has apparently resigned herself to «being one of the boys, which is virtually a job requirement when you do what she does, that she sometimes forgets the impact she makes of the opposite sex. (Silver, 2009: 2).

While women de-sexualise themselves on the trading floor men consume female traders as the ultimate spectacle in these novels, pouring over and analysing them in an attempt to decode why they would end up in such a masculine environment.

Ali ends the novel balancing work and a child as a single mother, with the support of Cassie and her employment but struggling to «have it all». Recessionista fiction is concerned with interrogating the reality of balancing a job and children for the twenty-first century career conscious female. In Hedge Fund Wives, Marcy is told in hushed tones about a type of HFW «the Workaholic», who «like her husband [...] is married firstly to her high-powered job as a magazine publisher/ interior decorator/ real-estate broker/ corporate lawyer. She has no children and has talked herself into believing that she'll be able to easily reproduce up until the age of fifty» (Boncompagni, 2009:17). The world of employment in Hedge Fund Wives is also littered with anecdotes about women betraying other women in the pursuit of marriage or careers. Marcy is «screwed over» for promotion by a female colleague in her old bank and asks «Why is it that women turn against each other like that? We should be supporting each other, not masterminding each other's firings» (Boncompagni, 2009: 300). When she meets a young business woman, Justine, she is not surprised at her complaints that «none of the guys want to date me because I'm too smart [...] the fact that I graduated magna cum laude from Yale is actually an impediment. Jesus, I just want to find a husband, you know?» (Boncompagni, 2009: 301). Fuelled by these experiences, the betrayals of her husband, and women who chose to operate like men in the workplace, Marcy uses the proceeds from her divorce to set up «Demeter and Co. [...] a female friendly working environment» in which it is «easier for the moms [...] to balance motherhood and work» and sends «a handful of our most promising interns [...] through college via the scholarship program» (Boncompagni, 2009: 346-7). 
The focus Hedge Fund Wives takes on matters of employment, independence and sisterhood was central to the stated aims of author Boncompagni in creating a Recessionista novel. She argues

I'm a big believer that all married women should keep working and networking even if they don't «have» to, because not only will their husbands respect them more for it, but they will respect themselves more for it, too [...] One of the main themes of Hedge Fund Wives is how foolish it is to depend on a man for your emotional and financial security. (Boncompagni, 2009: 358)

Boncompagni uses Recessionista fiction to examine the impact of the crunch on "women whose lives revolved not around status but money and the consumption of material goods» (Boncompagni, 2009: 355). Mining the meaning of such a period proved an appropriate context for fiction, since «periods of great economic volatility are rich with drama». Deliberately setting the novel in such «a period of tremendous uncertainty», she was conscious that «the economic downturn would change the dynamics» (Boncompagni, 2009: 356) of the text, enabling her to explore the ways and means by which female characters handled the redistribution of capital in the wake of the financial crisis. Hedge Fund Wives accordingly ends with a narrative outlook beyond the credit crunch, to an envisioned time when «Americans started saving more and spending less, and the national average household debt began to decline for the first time in dozens of years» (Boncompagni, 2009: 351).

As «quite literally a man-made disaster, a monster created in the testosterone-drenched environment of Wall Street and the City», the credit crunch has been offered as the logical product of a male dominated banking sector (Sunderland, 2009). In an article in the Financial Times in 2008, Gillian Wilmot speculated that if women occupied more top positions in the banking world then the credit crunch might never have happened. She argued that «the more financially rewarding the task the more men», and that the credit crunch in particular saw «a lethal combination of testosterone, complexity and greed» bring the UK «to its knees» (Wilmot, 2008). This lack of representation at the highest levels of the sector at the centre of this crisis has become the subject of widespread debate centring on gender imbalances at the heart of banking. In 2007, women held 13 executive directorships on the boards of FTSE 100 companies, or $3.6 \%$ of the total. There were 110 female non-executive directors, $14.5 \%$ of the total (Sutherland, 2009). Anna Cecilie Holst, a board director on several companies with 26 years' experience in the financial and venture/ start-up industry, summarised this argument in her statement that «basically by nature, women are more risk averse. I don't think Lehman Sisters would have taken the same risks as Lehman Brothers» (Holst in Casu Lukac, 2008). 
In Recessionista fiction, women do not function to domesticate the world of finance and business, but navigate the credit crunch to participate as equals on the trading floor, direct their own careers and households and cultivate successful relationships. These texts are significant because they take a pronounced feminist stance on the credit crunch and its aftermath: heroines end up not with more money, but with a more developed sense of self, taking charge of their own identities. In doing so, their authors have achieved a deeper connection to a situation that more accurately mirrors the situation of the reader. Ultimately, Recessionista fiction offers irony, agency, independence and economic acumen as key to surviving the crunch and its aftermath. The women of the crunch are not represented as heterogeneous like the men of the trading floors and hedge funds, but as diverse and responsive to the after effects of the crunch. Even Cosmopolitan magazine suggests that Recessionista fiction is finally «something good [...] to come of this recession after all. Bring on the tales of women who are drowning in debt, unlucky in love and actually have to go to work to earn a living» (Cosmo Team, 2009). Bringing a taste of reality to a chick lit in danger of extinction, Recessionista fiction calls for less heels and more financial and feminist awareness in contemporary literary representations of working women.

Complicit in creating the crunch and credit culture but more restorative and adaptive in its wake, the heroines of Recessionista fiction stand independent of their male counterparts who remain in the wounded financial sector. Instead, these women use their own cultural and economic capital for social good, empowering themselves, other women or smaller, independent businesses to ensure that diversity and sustainability become the foundations for future success. Recessionista fiction is significant not only for making visible and analysing the relationship between gender and debt in the twenty-first century, but also because it offers a model for the potential of the financial world as a hitherto underused setting in contemporary women's fiction. Faced with shrinking finances and fallouts from diminished incomes through divorce, the crunch and unemployment, the heroines of Recessionista fiction mobilise their reduced resources and transform misfortune into a muse and draw upon reserves they didn't know they had, to enable personal transformations in the wake of the global credit crunch.

\section{References}

Boncompagni, T. (2009): Hedge Fund Wives, Avon, London.

Casu Lukac, B. (2008): "The WOMEN-omics special report on the credit crunch», 20-First: Building Gender-Balanced Business. <http:/www.20first.com/408-0-expert-view-on-the-credit-crunch.html>. 
Cosmo Team (2009): «Is Chick Lit Out of Touch With Reality?», Cosmopolitan Magazine, 4 September. <http://www.cosmopolitan.co.uk/_mobile/lovesex/is-chick-lit-out-of-touch-reality-93735? ignoreCache $=1>$.

Ferriss, S. (2005): Chick Lit: The New Woman's Fiction, London, Routledge. La Ferla, R. (2009): «More Gumpton, Less Gucci» The New York Times, 13 August. <http://www.nytimes.com/2009/08/13/fashion/13 CHICK. html?pagewanted $=$ all\&_r $=0>$.

Mesure, S. (2009): «End of a Chapter: Chick Lit Takes on The Credit Crunch», The Independent, 30 August. <http://www.independent.co.uk/ arts-entertainment/books/news/end-of-a-chapter-chick-lit-takes-on-thecredit-crunch-1779378.html>.

Pine, K. J. (2009): «The Credit Crunch and you: Survey Report», Sheconomics, May. <http://www.sheconomics.com/downloads/credit_crunch.pdf > .

Philips, D. (2006): Women's Fiction: 1945-2005, London, Continuum.

RAKE, K. (2009): «Are women bearing the burden of the crunch? What data does and does not tell us», paper presented at The Credit Crunch: Gender Equality in Hard Times, Queens» College, University of Cambridge, Cambridge, 6 March.

Rosin, H. (2010): «The End of Men», The Atlantic, 8 July. <http://www. theatlantic.com/magazine/archive/2010/07/the-end-of-men/308135/>.

RoberTs, C. (2008): «Beyond boob jobs - how might the credit crunch affect women?», The F Word: Contemporary UK Feminism, 4 November. $<$ http:// www.thefword.org.uk/features/2008/11/beyond_boob_job $>$.

Silver, A. (2009): Confessions of a Reluctant Recessionista, London, Arrow.

SunderLAND, R. (2009): «The Real Victims of the Credit Crunch? Women», The Observer, 18 January. <http://www.guardian.co.uk/lifeandstyle/2009/ jan/18/women-credit-crunch-ruth-sunderland $>$.

WiLmot, G. (2008): «Men Have Messed Up. Let Women Sort it Out», Financial Times, 26 November. <http://www.ft.com/cms/s/0/c7dcb27c-bbc3-11dd80e9-0000779fd18c.html>. 